\title{
Satellite Sanitary Systems in Kampala, Uganda
}

\author{
Sammy Letema,, ${ }^{1, *}$ Bas van Vliet, ${ }^{2}$ and Jules B. van Lier ${ }^{3}$ \\ ${ }^{1}$ Department of Environmental Planning and Management, Kenyatta University, Nairobi, Kenya. \\ ${ }^{2}$ Environmental Policy Group, Wageningen University, Wageningen, The Netherlands. \\ ${ }^{3}$ Department of Water Management, Section Sanitary Engineering, Delft University of Technology, Delft, The Netherlands.
}

Received: February 4, $2011 \quad$ Accepted in revised form: June 5, 2011

\begin{abstract}
Satellite sewage collection and treatment systems have been independently developed and managed in East African cities outside the centrally planned and sewered areas. A satellite approach is a promising provisioning option parallel to public sewerage for middle- and high-income residential areas, endowed institutions, and government facilities. Although the studied satellite systems offer localized solutions that fit the situation of Kampala, better treatment and management arrangements are needed. Such arrangements do not readily conform to centralized or decentralized sanitation paradigms and likely require flexible mixtures of the two into modernized mixtures. In the case of Kampala, such mixtures entail regulation and control by centralized agencies, development and management by decentralized satellite providers, hybrid treatment process, and separation of waste(water) flows.
\end{abstract}

Key words: urban sanitation; decentralization; small-scale sewerage; management; modernized mixtures; Kampala; East Africa

\section{Introduction}

$\mathbf{P}$ UBLIC SEWERAGE COVERAGE in large towns of developing countries is dismal in most cases; and this situation is likely to remain, as governmental agencies in such countries are not capable of providing other infrastructural utilities in the future than the way they have been doing in the past (Lee and Floris, 2003). The inability of public sewerage agencies to develop sewerage facilities in tandem with city growth calls for alternative sewerage provision arrangements and a shift toward promotion of multiple systems (Crites and Tchobanoglous, 1998; Van Lier and Lettinga, 1999; Ho, 2005; Van Dijk, 2008; Gikas and Tchobanoglous, 2009; Massoud et al., 2009). One of the feasible shifts to alternative sanitary provision in East African cities is to establish decentralized satellite sewerage and treatment systems. In satellite areas, decentralized spatial planning, sewerage, and treatment are converging to provide small-scale solutions aimed at curbing urban informality, spread of insanitary conditions, and environmental pollution. This article aims at demonstrating that with better treatment technology choices and management arrangements than currently is the case, decentralized satellite sewerage and treatment systems can offer a viable

${ }^{*}$ Corresponding author: Department of Environmental Planning and Management, Kenyatta University, 43844-00100 Nairobi, Kenya. Phone: +254-2-8710901 ext 57221; E-mail: sletema@yahoo.com alternative for providing sanitary services at intermediate scale in East African cities, with Kampala serving as a case study.

\section{Methodology}

The article is based on case studies of five satellite sewerage systems cases out of eight existing in Kampala: Bugolobi, Naalya, Namboole, Ntinda, and Unise; whereas those left out are Luzira, Mukono, and Kyambogo. The five cases are chosen because they are more accessible, have operated for longer, and most treatment stages are operational. Assessment was done through interviews with satellite owners and operators, residents living close or being served by satellite systems, a Kampala city planner, a sewerage consultancy firm, and public health officers. The assessment included structured observations aided by checklists, and content analysis of practical reports. Seven grab samples were used for performance assessments ${ }^{\dagger}$ for total suspended solids (TSS), chemical oxygen demand (COD), ammonium nitrate $\left(\mathrm{N}-\mathrm{NH}_{4}\right)$, and total phosphate (TP), whereas the five grab samples done in February were used to assess performance of fecal coliform counts. Water column sampling was utilized, which is rapid, suitable for ponds, and not dependent on the time of the day (Pearson et al., 1987). Sampling and analysis

\footnotetext{
${ }^{\dagger}$ February 8, 15, 20, 22, and 27; July 17; and December 5, 2008.
} 
were done in conjunction with National Water and Sewerage Corporation (NWSC) as part of Lake Victoria Environment Management Program monitoring of pollution along Nakivubo-Inner-Murchison Bay in Lake Victoria. Effluents were analyzed using standard procedures (APHA, 1992).

\section{Satellite Sewerage and Treatment System as Modernized Mixtures}

A satellite system is a decentralized sewerage and treatment system that serves a defined outlaying area not connected to a central sewerage system. Satellite systems comprise an intermediate level between public large-scale sewerage and private on-site sanitation. Andoh (2004) described several advantages of satellite systems over centralized systems:

- saving costs by using small piping networks and reduced collection systems

- using less mechanical devices, thus low labor requirements with a scope for community management

- providing local treatment with a potential for local reuse

- ability to deliver high removal efficiency without relying on a more complex treatment process

- can be located upstream, thus resulting in reduced public health risks and effective utilization of assimilative capacity of the receiving environment

- offering low risks of disruption

In addition, they are less vulnerable to political instabilities and are less dependent on external funds, grants, and subsidies.

Inclusion of satellite sanitation systems in the overall sewerage and drainage management plan implies organization of sanitary infrastructures in certain geographical areas in multiple ways, resulting in a mix of scales, strategies, technologies, payment systems, and decision-making structures. As such, satellite systems could be an essential part of the proposed modernized mixtures (MM) approach as suggested by Spaargaren et al. (2005), van Vliet (2006), and Oosterveer and Spaargaren (2010). This can be done by modifying conventional systems to meet public health and environmental challenges; adopting nonconventional design principles and technologies; applying innovative organizational formats, novel scientific knowledge, and techniques; and optimally merging strengths of centralized and alternative sanitation in development of intermediate level sanitary services that are technically, socially, and locally sustainable.

For fitting satellite sanitary systems into an MM, a diverse set of social and technical aspects are taken into account to assess sanitation systems, including technical and spatial scale; scope of management between centralized and decentralized organization; combination or separation of waste(water) flows; and use of conventional or noncoventional technology. These aspects are examined for the five satellite systems in Toward Modernized Satellite Sewerage and Treatment Systems section (Fig. 1).

\section{Kampala Sewerage Infrastructure Growth and Emergence of Satellite Systems}

The first sewerage plan in Kampala was prepared in 1930 and was based on the separation of storm water and sewage. The plan targeted the whole township and was gradually extended over the water distribution area but excluded the socalled African areas. It drew, to a large extent, on British design practice and norms (Nilsson, 2006). A second sewerage plan

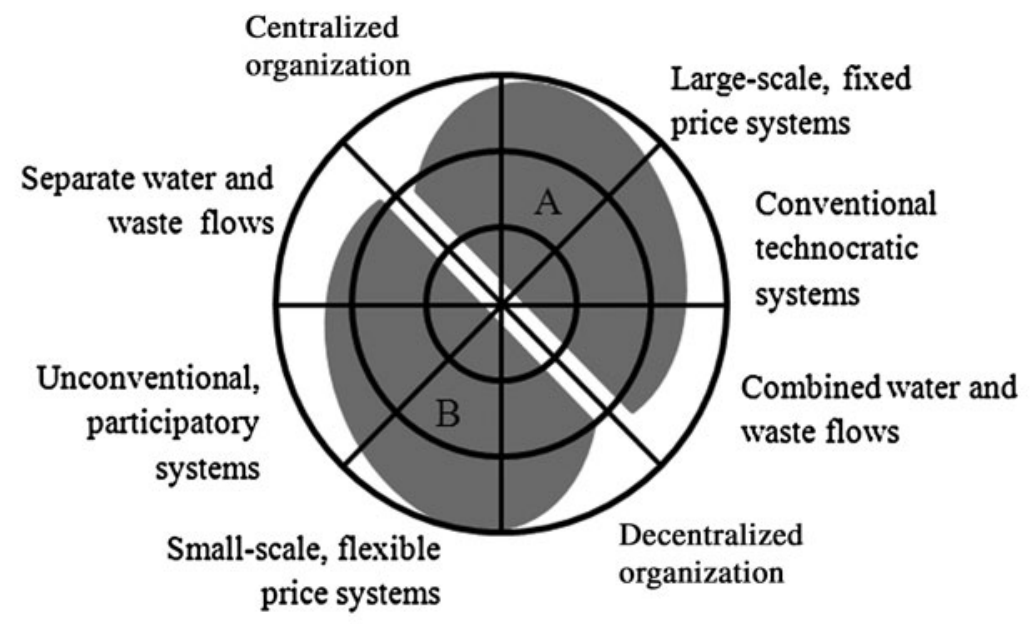

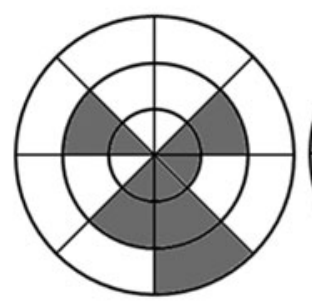

Unise

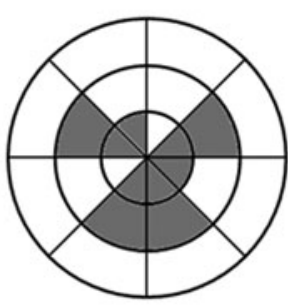

Bugolobi

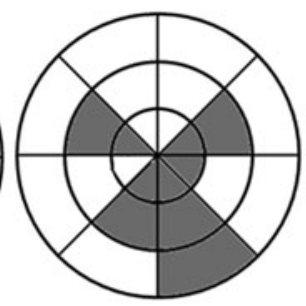

Ntinda

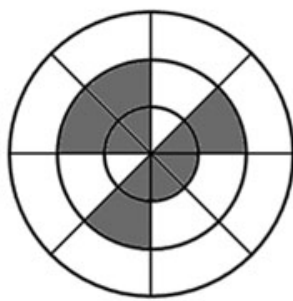

Namboole

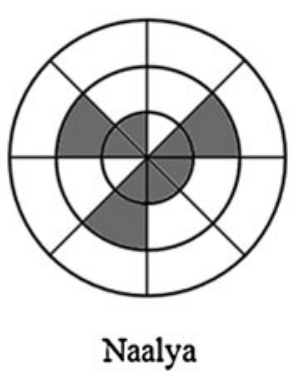

Naalya

FIG. 1. Kampala satellite systems as modernized mixtures, alternative to centralized sewerage (A) and on-site sanitation (B). 
Table 1. Analysis of Kampala Satellite Systems

\begin{tabular}{|c|c|c|c|c|c|}
\hline Parameters & Bugolobi & Unise & Naalya & Namboole & Ntinda \\
\hline Size (Ha) & 24 & 90 & 42 & - & 44 \\
\hline Year built & 1970 & 1964 & 1998 & 1997 & 1993 \\
\hline Developer & NHCC & Institute & NHCC & Government & NHCC \\
\hline Income status & Middle & Endowed & Middle & Endowed & Middle \\
\hline Design p.e. & 1050 & 720 & 4600 & 1500 & 3200 \\
\hline Current p.e. & 4800 & 780 & 2000 & 1500 & 1500 \\
\hline Design concept & F-M & F-F-M & A-F-F-F & F-F-M & F-F-M \\
\hline Operating concept & F-F & F-F-M & F-M-M-M & F-F-M & F-M-M \\
\hline Treatment area $\left(\mathrm{m}^{2}\right)$ & 4200 & 2000 & 13,300 & 3200 & 9300 \\
\hline Volume $\left(\mathrm{m}^{3}\right)$ & 4300 & 1800 & 17,900 & 3600 & 9300 \\
\hline Design capacity $\left(\mathrm{m}^{2} /\right.$ p.e. $)$ & 4 & 2.8 & 1.8 & 2.1 & 2.9 \\
\hline Current capacity ( $\mathrm{m}^{2} /$ p.e.) & 0.9 & 2.6 & 6.7 & 2.1 & 6.2 \\
\hline Retention time (days) & 6 & 33 & 26 & 23 & 42 \\
\hline Position & Series & Series & Series & Series & Series \\
\hline Load/capacity (\%) & 429 & 109 & 43 & 100 & 47 \\
\hline Pretreatment step & Absent & Absent & Present & Absent & Absent \\
\hline Flow meter & Absent & Absent & Present & Absent & Absent \\
\hline By-pass channels & Absent & Absent & Present & Absent & Absent \\
\hline Desludgeable & No & No & No & No & No \\
\hline TSS (mg/L) [100] & $146(48)$ & $20(11)$ & $52(31)$ & $143(61)$ & $115(58)$ \\
\hline $\mathrm{COD}(\mathrm{mg} / \mathrm{L})[100]$ & $148(91)$ & $56(25)$ & $69(27)$ & $130(70)$ & $93(28)$ \\
\hline $\mathrm{NH}_{4}-\mathrm{N}^{\mathrm{a}}(\mathrm{mg} / \mathrm{L})[10]$ & $23(9)$ & $5(7)$ & $17(10$ & $7(6)$ & $6(3)$ \\
\hline $\mathrm{TP}-\mathrm{P}$ (mg/L) [10] & $12(4)$ & $5(3)$ & $8(3)$ & $5(4)$ & $7(3)$ \\
\hline $\mathrm{FC}(\mathrm{MPN} / 100 \mathrm{~mL})[1 \mathrm{E} 4]$ & $1.0 \mathrm{E} 4(3.6 \mathrm{E} 3)$ & 3.0E3 (9.3E2) & $8.0 \mathrm{E} 3(4.0 \mathrm{E} 3)$ & $5.6 \mathrm{E} 3(1.8 \mathrm{E} 3)$ & 4.4E4 (4.6E4) \\
\hline
\end{tabular}

${ }^{a}$ Effluent discharge standards in Uganda are stringent, contradictory, and unrealistic. For instance, nitrogen and phosphorous removal is contradictory, as $\mathrm{NH}_{4}-\mathrm{N}$ is the same as $\mathrm{N}$; whereas the sum of $\mathrm{NO}_{3}, \mathrm{NH}_{4}-\mathrm{N}, \mathrm{NO}_{3}$, and $\mathrm{NO}_{2}$ is much greater than the limit for total nitrogen.

A, anerobic; COD, chemical oxygen demand; F, facultative; FC, fecal coliform; M, maturation; MPN, most probable number (technique for detecting and enumerating Pseudomonas aeruginosa in water and wastewater); NHCC, National Housing and Construction Company (Uganda); p.e., population equivalent; TP, total phosphate; TSS, total suspended solids;-, data not available; [], discharge requirement; (), standard deviation.

was developed in 1951, which guided sewerage development from 1958 to 1998. Eventually, it has taken public sewerage 80 years to cover $5 \%$ of the population and $10 \%$ of the urban area; whereas it still follows colonial spatial and sewerage planning legacy. The current sewerage plan envisages $25 \%$ population coverage by 2033. Inability of public sewerage to keep pace with both population and spatial growth offers satellite sewerage a chance for growth. It has taken satellite sewerage about 5 years to rise from $0.8 \%$ in 2004 (NWSC, 2004) to $1.4 \%$ of sewered population currently. This make thems account for $21.5 \%$ of sewer population, which positions it as a parallel sanitary provision pathway in Kampala.

At present, satellite systems are starting to be institutionalized through their incorporation in the current sanitation master plan (NWSC, 2004). The plan acknowledges their existence and contribution as parallel sewerage. Second, deliberate attempts have been made to stimulate private sector efforts in their development of affordable, planned, and serviced settlements to bridge a housing deficit that is estimated at 100,000 units. ${ }^{\star}$ A satellite approach offers a better impetus for such initiatives. Third, satellite systems are now stipulated for in a regulatory framework (Uganda, 1995a, 1995b, 1997, 1998, 1999). The combination of regulations provides for the following:

1. development of private sewerage systems under supervision and approval by the state sewerage agency;

Through reduced value, added tax by Ministry of Finance in 2007/08 National Budget on sale of residential properties, from $18 \%$ to $5 \%$ (Kayizzi, 2010).
2. connection of private sewerage to public sewers or operated as a decentralized system;

3. appointment of a sewerage authority to manage a sewerage area in all cases;

4. sewerage development in accordance with code and standard of workmanship;

5. treatment works to meet discharge standards, operate with discharge permit and monitoring compliance;

6. payment of annual waste discharge and regulatory fees by a holder of waste discharge permit;

7. levying of approved sewerage tariffs to meet management costs and regulatory fees.

\section{Assessment of Kampala Satellite Systems}

Satellite settlements are a product of blocks of land acquired, planned, and serviced; and they meet planning criteria for decentralized planning purposes (Nkurunziza, 2007). They are located in peri-urban areas and are small scale in terms of population, area, network size, and treatment (Table 1; Fig. 1). They were developed in the 1960s for government facilities, the 1970s for government residential schemes, and from 1990s onward for private residential, institutional, and governmental facilities (Table 1).

So far, satellite sewer characteristics (their location, size, and materials) have been inadequately documented. Interviews with sewerage managers, field observation, and examination of technical reports revealed that satellite sewerage (a) is conventionally designed and constructed with a high 
number of manholes and pipes laid along the road at considerable depths; (b) their designs were supervized and approved by the city council in 1960s and 1970s, whereas since 1990s, private consultants have designed and implemented with state sewerage agencies in a supervisory role; (c) sewer materials are mainly concrete for the 1960s and 1970s and PVC, from 1990s onward; and (d) assessed sewer lines are generally in good working conditions with no reported cases of sewer collapse, blockages, or overflows. However, the inlet pipe to Bugolobi ponds, a treatment system connected to one of the satellite sewer systems, was broken without repair for a decade.

The currently collected satellite sewage is mainly treated by waste stabilization ponds consisting of 2-4 ponds in series with effluent discharge to rivers and wetlands. Most ponds, except Naalya, are not provided with a screen, a flume, or bypass control valves, thus not permit desludging of individual ponds while operations are being maintained in others (Table 1). Naalya's last two ponds have fish stock that personnel fish for subsistence or extra income.

The studied satellite treatment systems lack any form of monitoring and inventory records. A monitoring survey for this study showed that performance is mixed: some meet effluent standards, whereas others do not. Overloaded ponds show weak performance compared with those operated at design load or below design capacity (Table 1). Remarkably, they perform better than the centralized systems when compared with monitoring records between May 2008 and May 2009: having the following constituents averages and standard deviation () concentrations in the effluent COD 276 (168), TSS 196 (84), N-NH 46 (66), and TP 15 (11) mg/L, and CFU $\left(1.60^{4}\left(9.9^{3}\right) \mathrm{MPN} / 100 \mathrm{~mL}\right)$.

The low performance of ponds is attributed to overloading, low retention time, omission of maturation ponds in some, and poor maintenance regime. Some ponds are covered by duckweed or contain large amounts of algae. Algae may contribute to high concentrations of TSS in effluents, which together with nutrients ( $\mathrm{N}$ and $\mathrm{P}$ ), are then hardly removed in pond systems (Cosser, 1982; Mara, 1996). Maturation ponds are on average over a meter deep. Most optimal performance is attained in shallow depths of less than a meter down to $30 \mathrm{~cm}$ (Silva et al., 1995), but for practical purposes, a depth of $1 \mathrm{~m}$ is generally applied. The designed depths of maturation ponds are Bugolobi $(1.21 \mathrm{~m})$, Unise $(1.14 \mathrm{~m})$, Namboole $(1.05 \mathrm{~m})$, and Ntinda $(0.89 \mathrm{~m})$ (NWSC, 2004).

Satellite systems are developed by multiple providers to serve peri-urban areas. Most developers are also operators (Table 1). Ntinda and Namboole, however, are managed by Ntinda Neighborhood Association and Sports Management Council, respectively. The state sewerage agency, Directorate of Water Development, have not yet appointed sewerage authorities for satellite areas. Operators, mostly hired casual workers, are unskilled for the required job. Management regimes such as desludging schedules, expansion plans, service charges, and fees are lacking. Moreover, payments of discharge, monitoring, and user fees are lacking.

\section{Toward Modernized Satellite Sewerage and Treatment Systems}

Satellite systems prove to be useful and necessary in Kampala, but significant inadequacies exist in most of the systems. The inadequacies are attributed to the poor management of the apparent centralized and decentralized approach in satellite system provision (Fig. 1):

- small-scale but lacks flexible mechanisms for sewerage charges and fees;

- conventionally planned, designed, and constructed without end-user involvement;

- water and waste flows are separate: storm water is separated from sewage and provided by city council, water is supplied by sewerage corporation whereas sewage flows are land use or facility specific, combined as domestic sewage and provided by satellite providers, with little reuse;

- decentralized management without adequate central control: lack of appointing of sewerage authorities to manage satellite areas, monitoring compliance, and mechanisms for asset transfer and ownership when properties are sold to individuals.

The top circle in Fig. 1 shows all the possible options in sanitary transformation. There is no ideal picture of MM due to the diversity in technology applications and providers. However, any mixture would be better than one of the extreme options: centralized (A) or decentralized (B).

Table 2. Centralized and Decentralized Aspects in Satellite Systems

\begin{tabular}{|c|c|c|}
\hline Aspects & Centralized & Decentralized \\
\hline Technology & $\begin{array}{l}\text { Approvals, guidelines and standards } \\
\text { Design and construction protocols } \\
\text { Supervision and monitoring }\end{array}$ & $\begin{array}{l}\text { Installation of system } \\
\text { Technology choice }\end{array}$ \\
\hline Regulation & $\begin{array}{l}\text { Permits, licensing, and registration } \\
\text { Tariff setting and approval }\end{array}$ & $\begin{array}{l}\text { Regulation by local by-laws } \\
\text { Tariff indexation }\end{array}$ \\
\hline Operation and maintenance & $\begin{array}{l}\text { Appointment of satellite sewerage authorities } \\
\text { Monitoring of performance contracts }\end{array}$ & $\begin{array}{l}\text { Investment plans } \\
\text { Performance management contracts }\end{array}$ \\
\hline $\begin{array}{l}\text { Planning, design, } \\
\text { and construction }\end{array}$ & $\begin{array}{l}\text { Approval and supervision } \\
\text { Code of workmanship as guideline }\end{array}$ & $\begin{array}{l}\text { Flexible designs and construction to suit } \\
\text { local conditions }\end{array}$ \\
\hline Wastewater provision & $\begin{array}{l}\text { Storm water management by council and } \\
\text { wastewater by sewerage agency at city level }\end{array}$ & $\begin{array}{l}\text { Localized management of storm water } \\
\text { and wastewater by satellite developers } \\
\text { at satellite level }\end{array}$ \\
\hline
\end{tabular}


The inadequacies have caused misperformance and unsustainability in satellite systems, which require three remedial measures:

1. To establish a mix of centralized and decentralized management for managing the satellite sewers and treatment systems (Table 2). Some responsibilities are better performed by centralized state agents, others when decentralized, and some when shared. Complete decentralization of satellite systems is undesirable and prone to mismanagement, whereas centralization is untenable and may kill prevailing provision inertia. Consequently, a mixture is likely to provide better impetus for rapid implementation and management.

2. Separation of asset ownership from operation and maintenance for better management. This calls for appointment of sewerage authorities to manage them and to obtain financial sustainability. Sustainable financial mechanisms can be achieved by the following:

a. Introduction of sewerage tariffs in residential areas. Satellite systems are potentially sustainable if indexation of electricity costs, management fee, regulation fee, and discharge fee are included in tariffs.

b. A management fee. Endowed institutions and government facilities that periodically generate substantial income can conclude a management contract with private firms. Those that do not generate income can have fees paid through budgetary allocations.

c. Waste valorization. Pond systems can be modernized from waste water treatment systems to production centers through waste valorization and fish aquaculture. In Calcutta, India, waste stabilization ponds are profitable fish-production centers, with fees paid by fish cooperatives able to operate and maintain treatment systems (Kamal et al., 2008). In such a system, the protein-rich duckweed harvested from ponds is, for example, used as fish feed, thus resulting in high fish yields. The recovery of nitrogen by duckweed enhances treatment efficiencies and financial sustainability (El-Shafai et al., 2007).

3. Alternative to the currently applied conventional pond systems, modern compact bio-treatment systems offer high treatment performances at relatively low costs and low space demands. Particularly modern compact anerobic high-rate technologies complemented with adequate post-treatment systems can provide a costeffective technology provision, independently from the electricity grid (Uemura and Harada, 2010; van Lier et al., 2010). Obviously, such systems are an attractive alternative to the compact systems in Mukono or one procured for Lubowa, which are aerobic and energy demanding.

\section{Conclusion}

Satellite sewerage systems are increasingly being developed in cities of the developing world as a result of public sewerage agencies' inability to provide sewerage services in tandem with urbanization. Satellite systems are promising, especially in situations of limited central sewerage not being in pace with extensive water supply, horizontal expansion, and growth of institutions and middle- and high-income groups that often require planned and serviced sites. This article shows that satellite systems which are applied in peri-urban areas are operated independently from centralized services. However, the treatment systems connected to these satellite systems are lacking adequate management and control. Several ideas for upgrading are proposed. Compared with central sewerage and treatment systems, satellite systems provide a viable localized sewerage and treatment pathway at a faster rate, against lower costs. They are custom made, enable wider actor collaboration, and can be financed fully from internal resource mobilization. If adequately managed, satellite systems are a viable intermediate-level sanitary services delivery in Kampala and East African cities, in general.

\section{Acknowledgment}

The authors would like to sincerely thank Dr. Joost van Buuren (Wageningen University) for his suggestions on an earlier version of this article.

\section{Author Disclosure Statement}

No competing financial interest exists.

\section{References}

Andoh, R.Y.G. (2004). Why satellite treatment within collection systems makes sense. Conference Proceedings on Collection Systems 2004: Innovative Approaches to Collection Systems Management. Milwaukee, WI, August 8-11.

APHA. (1992). Standard Methods for the Examination of Water and Wastewater Analysis. Washington, D.C.: American Public Health Association.

Cosser, P.R. (1982). Lagoon algae and the BOD test. Effluent Water Treat. 21, 357.

Crites, R., and Tchobanoglous, G. (1998). Small and Decentralized Wastewater Management Systems: An Overview. Boston: WCBMcGraw-Hill.

El-Shafai, A.S., El-Gohary, F.A., Nasr, F.A., and van der Steen, N.P. (2007). Nutrient recovery from domestic wastewater using a UASB-duckweed pond system. Bioresour. Technol. 98, 798

Gikas, P., and Tchobanoglous, G. (2009). The role of satellite and decentralized strategies in water resources management J. Environ. Manage. 90: 144-152.

Ho, G. (2005). Technology for sustainability: the role of onsite, small and community scale technology Water. Sci. Technol. $51,15$.

Kamal, A.S.M., Goyer, K., Koottatep, T., and Amin, A.T.M.N. (2008). Domestic wastewater management in South and Southeast Asia: the potential benefits of a decentralized approach. Urban Water J. 5, 345.

Kayizzi, R. (2010). 20 Years of Economic Recovery: Housing, Construction Sector Boom. Kampala: New Vision Newspapers.

Lee, T., and Floris, V. (2003). Universal access to water and sanitation: why the private sector must participate. Nat. Resour. Forum 27, 279.

Mara, D.D. (1996). Waste stabilization ponds: effluent quality requirements and implications for process design. Water Sci. Technol. 33, 23.

Massoud, M.A., Tarhini, A., and Nasr, J. (2009). Decentralized approaches to wastewater treatment and management: applicability in developing countries. J. Environ. Manage. 90, 652. 
Nilsson, D. (2006). A heritage of unsustainability? Reviewing the origin of the large-scale water and sanitation system in Kampala, Uganda. Environ. Urban. 18, 369.

Nkurunziza, E. (2007). Informal mechanisms for accessing and securing urban land rights: the case of Kampala. Environ. Urban. 19, 509.

NWSC. (2004). Sanitation Strategy and Master Plan for Kampala City: Volume 2. Kampala: National Water and Sewerage Corporation (NWSC).

Oosterveer, P., and Spaargaren, G. (2010). Meeting social challenges in developing sustainable environmental infrastructures in East African Cities. In B. van Vliet, G. Spaargaren, and P. Oosterveer, Eds., Social Perspectives on the Sanitation Challenge. Dordrecht: Springer, pp. 11-30.

Pearson, H.W., Mara, D.D., Konig, A., de Oliveira, R., Mills, S.W., Smallman, D.J., and Silva, S.A. (1987). Water column sampling as a rapid and efficient method of determining effluent quality and performance of waste stabilisation ponds. Water Sci. Technol. 19, 109.

Silva, S.A., de Olivera, R., Soares, J., Mara, D.D., and Pearson, H.W. (1995). Nitrogen removal in pond systems with different configurations and geometries. Water Sci. Technol. 31, 321.

Spaargaren, G., Oosterveer, P., van Buuren, J., and Mol, A.P.J. (2005). Mixed Modernities: Towards Viable Urban Environmental Infrastructure Development in East Africa. Wageningen: Wageningen University.

Uemura, S., and Harada, H. (2010). Application of UASB technology for sewage treatment with a novel post treatment process. In H.H. Fang, Ed., Environmental Anaerobic Technology; Applications and New Developments, Chapter 4. London: World Scientific, Imperial College Press, pp. 91-112.

Uganda. (1995a). National Water and Sewerage Corporation Act. Entebbe: Uganda Printing and Publishing Corporation.

Uganda. (1995b). Water Statute. Entebbe: Government Printer.

Uganda. (1997). The Local Government Act. Entebbe: Uganda Printing and Publishing Corporation.

Uganda. (1998). The Water (Waste Discharge) Regulations. Entebbe: Government Printer.

Uganda. (1999). National Environment (Standard for Discharge of Effluent to River or on Land) Regulations. Entebbe: Government Printer.

Van Dijk, M.P. (2008). Role of small-scale independent providers in water and sanitation. Int. J. Water 4, 275.

Van Lier, J.B., and Lettinga, G. (1999). Appropriate technologies for effective management of industrial and domestic waste waters: the decentralized approach. Water. Sci. Technol. 40, 171.

Van Lier, J.B., Vashi, A., van der Lubbe, J., and Heffernan, B. (2010). Anaerobic sewage treatment using UASB reactors: engineering and operational aspects. In H.H. Fang, Ed., Environmental Anaerobic Technology; Applications and New Developments. London: World Scientific, Imperial College Press, p. 59.

Van Vliet, B. (2006). The sustainable transformation of sanitation. In J.P. Voss, D. Bauknecht, and R. Kemp, Ed., Reflexive Governance for Sustainable Development. Cheltenham: Edward Elgar, pp. 337-354. 